\title{
EVOCATIO AND THE TRANSFER OF JUNO REGINA FROM VEII
}

\author{
Roman A. Isaenko
}

St. Petersburg State University, 7-9, Universitetskaya nab., St. Petersburg, 199034, Russian Federation; isaenkora@mail.ru

The subject of this short study is a legend that describes the transfer of a statue of Juno Regina, the patron goddess of Veii, to Rome in 396 BCE, shortly after the fall of the Etruscan city to the Roman forces led by Camillus. The legend is commonly interpreted as a depiction of evocatio, a ritual meant to convince the tutelary deities of a beseiged city to support the Romans. However, none of the multiple known accounts of the statue's transfer (the principal of which is provided by Livy) present it as a part of a ritual. The article aims to examine the validity of such a connection by closely comparing the events of the legend, their timing, and their nature to the ancient accounts of evocatio. Following this, a comparison is made to two other legends, preserved by Herodotus and Athenaeus (his source is Menodotus), both of which describe miracles displayed by the images of gods in response to the attempts to move them. On the basis of this comparison it is concluded that the legend of the transfer of Juno Regina is not meant to depict a particular ritual and has emerged merely to provide an explanation of the fact that the ancient Etruscan image has found its place in Rome. Refs 7.

Keywords: evocatio, Veii, Livy, Valerius Maximus, Dionysius of Halicarnassus, Plutarch.

Several Roman authors including Pliny the Elder (Nat. Hist. 28. 18) and Servius (Schol. in Aen. 2. 351) make mention of evocatio, the ritual of summoning the patron deity of a besieged city to the side of the Romans. The most extensive account is provided by Macrobius who introduces the ritual with the following passage:

constat enim omnes urbes in alicuius dei esse tutela moremque Romanorum arcanum et multis ignotum fuisse ut cum obsiderent urbem hostium eamque iam capi posse confiderent, certo carmine evocarent tutelares deos, quod aut aliter urbem capi posse non crederent aut etiam si posset, nefas aestimarent deos habere captivos (Sat. 3. 9).

"For it is commonly understood that all cities are protected by some god, and that it was secret custom of the Romans (one unknown to many) that when they were laying siege to an enemy city and were confident it could be taken, they used a specific spell to call out the gods that protected it, because they either believed the city could otherwise not be taken or - even if it could be taken - thought it against divine law to hold gods captive." (Transl. R. A. Kaster) 
The ritual is commonly connected to one of the many legends that surround the siege of the Etruscan city of Veii which fell to Roman troops commanded by Marcus Furius Camillus in 396 BCE. The legend concerns the removal of a statue of Juno Regina, the city's patron deity, and its subsequent transfer to Rome, where it was placed inside a temple located on the Aventine Hill. Livy describes this event as follows:

namque delecti ex omni exercitu iuuenes, pure lautis corporibus, candida ueste, quibus deportanda Romam regina Iuno adsignata erat, uenerabundi templum iniere, primo religiose admouentes manus, quod id signum more Etrusco nisi certae gentis sacerdos attractare non esset solitus. dein cum quidam, seu spiritu diuino tactus seu iuuenali ioco, 'uisne Romam ire, Iuno?' dixisset, adnuisse ceteri deam conclamauerunt. inde fabulae adiectum est uocem quoque dicentis uelle auditam; motam certe sede sua parui molimenti adminiculis, sequentis modo accepimus leuem ac facilem tralatu fuisse, integramque in Auentinum aeternam sedem suam quo uota Romani dictatoris uocauerant perlatam, ubi templum ei postea idem qui uouerat Camillus dedicauit (5.22).

"For out of all the army youths were chosen, and made to cleanse their bodies and to put on white garments, and to them the duty was assigned of conveying Queen Juno to Rome. Reverently entering her temple, they scrupled at first to approach her with their hands, because this image was one that according to Etruscan practice ${ }^{1}$ none but a priest of a certain family was wont to touch; when one of them, whether divinely inspired or out of youthful jocularity, asked, "Wilt thou go, Juno, to Rome?" - whereat the others all cried out that the goddess had nodded assent. It was afterwards added to the story that she had also been heard to say that she was willing. At all events we are told that she was moved from her place with contrivances of little power, as though she accompanied them voluntarily, and was lightly and easily transferred and carried safe and sound to the Aventine, the eternal home to which the prayers of the Roman dictator had called her; and there Camillus afterwards dedicated to her the temple which he himself had vowed." (Transl. B. O. Foster).

The legend is retold by Valerius Maximus (1. 8. 3), who mistakenly refers to the deity as Juno Moneta, as well as by Dionysius of Halicarnassus (Ant. Rom. 13. 3), who adds that the young Romans failed to trust their own senses and, having received the goddess' reply, asked the same question once more only to receive the same answer again.

Of particular note is Plutarch's retelling (Cam. 6), according to which it was Camillus himself who touched and addressed the image of Juno. However, because Plutarch names Livy as his source, it can be assumed that the Greek historian merely forgot about the young warriors, never again mentioned by Livy, and naturally ascribed their actions to Camillus, the man who plays the most prominent part in the $5^{\text {th }}$ book of Ab Urbe Condita. Another, less likely possibility is that Plutarch knew of a different version of the legend that he misattributed to Livy.

Despite Livy, Valerius Maximus, Dionysius, and Plutarch never claiming that the events that accompany the siege are meant to constitute a ritual, it is tempting to associate the legend with evocatio because the Roman assault is preceded by Camillus' vow to Juno Regina (5.21), which resembles a formula given by Macrobius. ${ }^{2}$ R. Ogilvie concludes that

1 Robert Ogilvie notes that a similar custom existed in Rome itself, where the priesthood of Hercules was an exclusive domain of two families, Potitii and Pinarii (Ogilvie 1965, 678).

2 The address of Camillus and the formula allegedly used during the siege of Carthage are very much alike: both deities are asked to leave their city in favor of a new temple in Rome. However, Juno Regina is invited to follow the victors, albeit Macrobius stresses that the patron deity is meant to leave before the city 
Livy used the same formula as a base when writing Camillus' address to Juno. ${ }^{3}$ Gabriella Gustafsson uses the legend to reconstruct the course of evocatio in greater detail and explains the contrast between Livy's reluctance to believe in the statue's ability to speak and his apparent readiness to believe in its no less miraculous ability to nod by suggesting that the ritual possibly required the participants to pretend that the image of the deity being summoned nodded in response to their invitation and to express astonishment at this imaginary nod. ${ }^{4}$ S. Rutledge calls the transfer of the statue of Juno "the most famous instance" of evocatio. ${ }^{5}$ J. Kloppenborg retells the legend of Veii, "the earliest reported instance of evocatio," to make his readers familiar with the concept of evocatio in an article interpreting the prophecy of the destruction of the Second Temple found in the Gospel of Mark as a reference to this ritual. ${ }^{6}$ Investigating the relationship between evocatio and devotio $\mathrm{H}$. Versnel also presents the relocation of Juno Regina as an example of evocatio: "Moreover, about Veii and Carthage we know that an evocatio of the tutelary goddess had taken place. In Veii this was Iuno Regina, and Livy 5, 21-23 gives a circumstantial account of the whole affair." Kurt Latte goes as far as to assert that the siege of Veii is the only well-attested case of the use of evocatio: "In der Frühzeit mag der Ritus öfter vollzogen worden sein, aber einen Beleg kennen wir nur von der Iuno Regina aus Veii."

It should be noted that Livy does use the verb evocare in reference to Juno Regina shortly after the address of Camillus to her:

Veientes, ignari se iam a suis vatibus, iam ab externis oraculis proditos, iam in partem praedae suae vocatos deos, alios votis ex urbe sua evocatos hostium templa novasque sedes spectare seque ultimum illum diem agere, nihil minus timentes quam subrutis cuniculo moenibus arcem iam plenam hostium esse in muros pro se quisque armati discurrunt (5. 21. 5-6).

"The Veientes, unconscious that they were already given up by their own soothsayers, and by foreign oracles, that some of the gods had already been invited to share in their despoiling, while others having been entreated to quit their city were beginning to look to new homes in the temples of their enemies, and that this was the last day they were themselves to live, feared nothing less than that their defenses were undermined and their citadel already filled with foemen, and, each for himself, took up arms and ran out to the ramparts." (Transl. B. O. Foster.)

However, the verb itself is not a technical term that can only be used to denote the ritual described by Macrobius, as evidenced by its use in the Digest of Justinian (Dig. 1. 8. 9. 2):

is captured. Juno Regina also shares the spotlight with Pythian Apollo, addressed immediately before her, and it is him that Camillus considers to be his principal patron during the siege, promising one-tenth of looted treasure in return. Furthermore, the two addresses differ stylistically. The most distinguishing trait of the language of the formula preserved by Macrobius is the heavy use of strings of synonyms (for example, populum civitatemque or acceptior probatiorque) completely absent in Livy.

3 Ogilvie 1965, 671-5: "L. abbreviates the prayer prefacing it with an extraneous invocation of Apollo but $<\ldots>$ the elements of the original prayer are still perceptible. Instead of detailing the ritual as a ritual, L. made it part of the narrative, incorporating the different acts as historical episodes and recasting the prayer in literary language which conveys the atmosphere but not the uncouthness of actual devotion...

${ }^{4}$ Gustafsson 2000, 53.

${ }^{5}$ Rutledge 2007, 180.

${ }^{6}$ Kloppenborg 2005, 434.

7 Versnel 1976, 382.

${ }^{8}$ Latte 1960, 125. 
Illud notandum est aliud esse sacrum locum, aliud sacrarium. sacer locus est locus consecratus, sacrarium est locus, in quo sacra reponuntur, quod etiam in aedificio privato esse potest, et solent, qui liberare eum locum religione volunt, sacra inde evocare.

"A point that should be noted is that a sacred place is not the same thing as a sacrarium. A sacred place is a consecrated place, a sacrarium is a place in which sacred objects are kept, and it may exist in a private building; moreover, when persons wish to divest such a place of its religious character, they commonly have the sacred objects removed by evocation." (Transl. C. H. Monro).

In this passage the verb evocare appears to denote the act of removal of sacred objects from any place, under any circumstances. As Livy, uncharacteristically, does not take the opportunity to clarify that he speaks of a specific ritual and to offer additional insight into its nature and history, it can be assumed that he also uses the participle evocatos in a more general sense, as a parallel to the earlier instance of vocatos.

Comparing the actions of the young Romans described in the legend with the ancient accounts of evocatio reveals a number of discrepancies. First of all, both Macrobius and Pliny make it clear that the ritual was meant to be performed by a high-ranking official. Macrobius quotes the formula that was supposedly used during the siege of Carthage, and it refers to the Roman forces as militibus meis (Sat. 3. 9. 8), indicating that it is a military commander who speaks. Pliny, on the other hand, referencing Verrius Flaccus and his unnamed sources, claims that the charge of performing the ritual was entrusted to priests and specifically names the pontifices as the ones who still retained the knowledge of it in his day. Macrobius and Pliny are not necessarily at odds with each other: in Livy's depiction of a different wartime ritual, devotio, consul Publius Decius Mus asks a pontifex to dictate the formula for him (8.9), so it is possible that a pontifex offered similar guidance to a commander when evocatio was performed. Despite this, it is common warriors who address Juno in the legend of the capture of Veii. Instead of a formal rank, it is their youthful vigor and cleanliness that distinguish them from others and make them fit to approach a goddess.

The timing of the address also deserves attention. The purpose of evocatio, according to Macrobius, is either to make the capture of a city possible at all or to avoid capturing the patron deity along with the city (Sat. 3. 9. 2). This means that the ritual has to take place before the final assault, as Pliny, Servius, and Macrobius all attest. Contrary to this, the events that the legend describes take place after Veii has already fallen, and the looting has begun. Evocatio can no longer serve its primary function at this point.

Finally, Livy, Valerius Maximus, and Dionysius specify that the young Romans acted either in jest or under the effect of a divine inspiration. They had been given the task of removing the image, not of speaking to the goddess, and their address was a product of improvisation rather than a part of a memorized formula. A conscious reproduction of specific words and actions is what constitutes a ritual, any ritual, yet the legend stresses that the warriors acted by impulse.

If evocatio is not the subject of the legend in question, a different explanation of its origin should be presented. Statues that come to life - be it in order to foretell a future event (HA, Tacitus 17.5), to punish an offense (Luc. Phil. 19-20), or even to attempt to forcibly marry a man careless enough to put a ring on a golden finger (Gesta Regum Anglorum 2. 205, which Mérimée's La Vénus d'Ille can probably be traced back to) - make frequent appearances in legends and folktales. At least two legends documented in ancient sources bear a particular resemblance to the story of Juno Regina's relocation. 
One of these legends is recorded by Athenaeus who cites Menodotus of Samos (FGH 541, 1-2) as his source (Deipn. 15. 12; 671F-72F). According to this account, Admete, the daughter of Eurystheus, fled from Argos to Samos where she became a priestess of Hera, believing the goddess to be responsible for her success. The vengeful Argives hired Tyrrhenian brigands to steal the wooden image of Hera from her temple on Samos, hoping that Admete would be blamed for the loss. These events unfolded in the following manner:

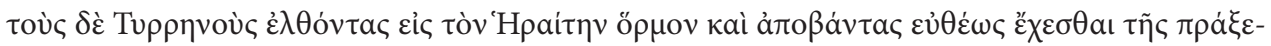

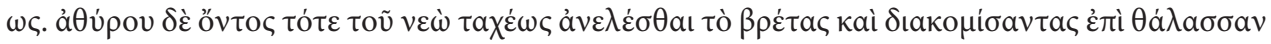

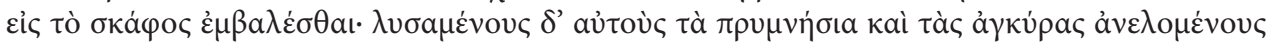

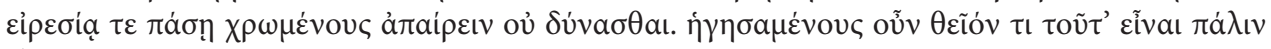

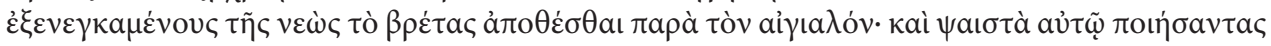

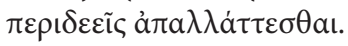

"So the Tyrrhenians made for the port of Hera, and disembarking set to work at once. Since the temple had no door at that time, they soon picked up the image and carried it to the sea, where they placed it in their ship; but though they loosed the cables, pulled up the anchors, and rowed with all their might, they could not get under way. Thinking, therefore, that it was a divine portent, they carried the image out of the ship again and deposited it on the shore; and setting barley-cakes beside it they departed in great fear." (Transl. C. B. Gulick).

After the Samians had discovered the image, they assumed that Hera had left the temple by herself, and a yearly festival of Tonaia was instituted. Whenever it was celebrated the image was brought to the shore again, where it received purification and offerings of cakes.

Another similar legend is recounted by Herodotus (5. 82-6). When the city of Epidaurus faced a famine, and its people sought the council of the Delphic oracle, the Pythia instructed them to appease fertility goddesses Damia and Auxesia by erecting images in their honor made of the wood of an olive tree. The olive wood was provided by the Athenians in exchange for a yearly tribute from Epidaurus. However, the Epidaurians ceased to provide the offerings after the images had been stolen by the Aeginetans, which resulted in Athenian troops being dispatched to Aegina so they could recover the statues. The images proved to be impossible to remove from their pedestals by hand, yet the Athenians persisted, bound the statues with ropes, and began to pull. Herodotus' sources differ on what followed exactly. The Athenian version of the legend claims that an earthquake accompanied by thunder occurred, which drove the Athenians mad and led to them killing one another. The Aeginetan variant maintains that both statues fell on their knees, which was followed by the Athenians being ambushed by the Argives who came to the Aeginetans' aid. Either way the displeasure of Damia and Auxesia was made apparent and the Athenians chose to abandon their attempts to recover the statues.

Both of these legends mirror the story told by Livy. In all three cases an image of a goddess displays its preference for a particular place by altering its own mass. When Juno Regina wishes to be brought to Rome, the Romans discover the statue to be peculiarly light and decide that it is so because the goddess herself is following them. When Hera (or the Epidaurian fertility deities) wish to stay on Samos (or Aegina), the Tyrrhenians (or the Athenians) find the image to be exceptionally heavy, prohibiting any movement. Notably, the removal of the statues in the Greek legend pursues purposes very different from that 
of evocatio: instead of facilitating a siege by removing divine protection, the Tyrrhenians are solicited to dishonor the keeper of the image, while the Athenians intend to give the statues back to the Epidaurians in exchange for tribute. Therefore, the practice of evocatio is not necessary for a legend of this type to appear. Furthermore, the Greek legends are etiological in character, in that both of them provide reasons for the unusual placement of the statues. The Samian legend describes the establishment of the custom of bringing the image of Hera to the shore, while the legend of Damia and Auxesia justifies the presence of the Epidaurian statues made of Athenian wood on Aegina. In addition, the Aeginetan variant provides justification for the unusual posture of the goddesses ${ }^{9}$. Therefore, it is possible that the legend of the image of Juno Regina came to exist for the same reason as the Greek legends: to provide a justification for an Etruscan statue having become the focal point of a Roman cult.

\section{References}

Gustafsson G. Evocatio Deorum. Historical and Mythical Interpretations of Ritualised Conquests in the Expansion of Ancient Rome. Uppsala, Uppsala University, 2000.

How W. W., Wells J. A. Commentary on Herodotus. Volume II (Books V-IX). Oxford, OUP, 1912.

Kloppenborg J. S. Evocatio Deorum and the Date of Mark. Journal of Biblical Literature 2005, 124/3, 419-450. Latte K. Römische Religionsgeschichte. München, C. H. Beck 1960.

Ogilvie R. M. A Commentary on Livy, Books 1-5. Oxford, OUP 1965.

Rutledge S. H. The Roman Destruction of Sacred Sites. Historia: Zeitschrift für Alte Geschichte 2007, 56/2, 179-195.

Versnel H.S. Two Types of Roman Devotio. Mnemosyne 1976, 29(4), 365-410.

For citation: Roman A. Isaenko. Evocatio and the Transfer of Juno Regina from Veii. Philologia Classica 2017, 12(1), 23-28. DOI: 10.21638/11701/spbu20.2017.103.

\section{EVOСАТІО И ПЕРЕНОС СТАТУИ ЈUNO REGINA ИЗ ВЕЙ}

Роман Андреевич Исаенко

Санкт-Петербургский государственный университет, Российская Федерация, 199034, Санкт-Петербург, Университетская наб., 7-9; isaenkora@mail.ru

В статье интерпретируется легенда, которая описывает перенос статуи Juno Regina, богинипокровительницы Вей, в Рим в 396 г. до н.э., вскоре после взятия города римскими войсками под предводительством Камилла. Легенда часто трактуется как описание evocatio - обряда, предназначенного для того, чтобы «убедить» божество-покровителя осаждаемого города поддержать римлян. Между тем, ни одно из нескольких известных свидетельств о переносе статуи Юноны (главное из которых предоставляет Ливий) не преподносит его как часть какого-либо ритуала. Рассмотрев сообщение Ливия на фоне древних свидетельств об еvocatio, автор статьи сопоставляет его с двумя другими легендами, переданными Геродотом и Афинеем, которые описывают чудеса, проявленные изваяниями богов в ответ на попытки сдвинуть их. На основании этого сопоставления автор заключает, что легенда о переносе Juno Regina предназначена не для того, чтобы дать описание конкретному ритуалу, но с целью объяснить, как древнее этрусское изваяние попало в Рим. Библиогр. 7 назв.

Ключевые слова: evocatio, Вейи, Ливий, Валерий Максим, Дионисий Галикарнасский, Плутарх.

Received 28.03.2017

Final version received 23.05.2017

9 The commentary on Herodotus by How and Wells provides a more convincing explanation, referencing Welcker and Frazer, by suggesting that Damia and Auxesia were goddesses of childbirth (How, Wells 1912, 48). 